\title{
Examination of Challenges Faced by Youth-Owned Small Medium Micro Enterprises in Limpopo Province of South Africa
}

\author{
Mamoloko F. Rachidi \\ University of Limpopo, Turfloop Graduate School of Leadership, PO Box 759, Fauna Park; \\ Polokwane 0787, Republic of South Africa \\ florah.rangongo@ul.ac.za
}

\section{Doi:10.5901/mjss.2014.v5n27p1258}

\section{Abstract}

There is universal consensus that countries, South Africa included, need to develop and support more small business owners, especially youth, to grow the economy and create more jobs. The South African government have put measures in place for support and development of youth-owned small businesses. Accordingly, it becomes essential to assess if these measures are achieving their objectives. The overall purpose of this paper is to assess the status of youth-owned small businesses in Limpopo Province of South Africa as well as challenges faced by these businesses. Data were collected by semi-structured interviews. The results indicated that the challenges youth face include a combination of lack of skills, finance, business supportive infrastructure and/or technology. Most of the youth were also not aware of the training and support programmes and policies offered by government and its parastatals. Furthermore, those who were aware still did not utilise the government support programmes. There was very little growth in their businesses over time, implying that theses youth-owned small businesses contributed little towards creating employment opportunities and developing and/or boosting the economy in their area. The paper recommended education and training; encouraging partnerships and joint ventures as well as help in accessing finance.

Keywords: youth development; small business challenges; youth unemployment; business support

\section{Introduction}

There are various ways of defining youth that are dependent on the context and purpose of the definition. The National Youth Policy 2009 - 2014 defines youth as any person between the ages of 14 and 35 years. Youth constitute the largest portion of the overall population in South Africa. According to Statistics South Africa (StatsSA, 2013) youth (ages 15 to 34) make up $36.6 \%$ of the population while those under 15 years of age make $29.2 \%$. This implies that young people under the age of 35 make up $65.8 \%$ of the population. Therefore, supporting and developing them in terms of their participation in the economy will go a long way towards developing the country and alleviating poverty as they are the future of the nation (National Youth Policy 2009 - 2014). The aim of this paper was to explore the situation of youth involvement in entrepreneurial activities/ventures within the Limpopo, South Africa.

According to StatsSA (2014) the overall unemployment rate in the last quarter of 2013 was $24.1 \%$, with women at $26.3 \%$ versus men at $22.4 \%$. However the expanded unemployment rate, which includes those unemployment people who are discouraged and are as a result no longer looking for work, was reported to be $35.1 \%$ in the same period. The unemployment rate for the Limpopo Province was standing at 19.1\% (expanded at 38.0\%). Youth unemployment rate is reported to be higher than the average in the country at $50.7 \%$ for the 15 to 24 age group and $29.8 \%$ for the 25 to 34 age group. This further highlights the importance of exerting more effort on helping and developing youth.

Although the South African economy has reportedly been growing at a rate of $4.5 \%$ per annum it has not been enough to absorb the growing labour force, especially youth. In addition, youth poverty in South Africa is reported to be due to 1) the youth continuously relying on poor household and 2) high levels of youth unemployment. One of the ways that can be utilised to curb the challenges of unemployment and poverty are through entrepreneurship and/or small businesses. The government of South Africa considers the development and support of Small business enterprises to be key in economic development, alleviation of poverty and job creation (The Department of Trade and Industry [DTI], 2008). As a result, several policies and strategies were initiated by government to develop and support Small business enterprises, in particular, those owned by youth, women and the disabled (Integrated Strategy on the Promotion of Entrepreneurship and Small Enterprises). Some of the initiatives are aimed specifically at assisting youth with for instance, awareness of youth SMME enterprises, access to financial and non-financial services (The National Youth 
Economic Empowerment Strategy, 2009 - 2019) as well as the promotion of youth owned/managed businesses and increasing the number of policies that can help in developing youth in the country (Youth Enterprise Development Strategy [YEDS], 2013 - 2030).

So since the introduction of support measures for SMMEs, especially support for youth entrepreneurs there have been improvements in the number of youth starting business ventures. As a result, there needs to be some analysis of how those businesses are doing as part of what the Integrated Strategy on Promotion of Entrepreneurship and Small Enterprises seeks to do.

South Africa, like most countries, identified SMME development as one of the priorities that can help in developing the economy. It is with the view that some initiatives were put into place to support small businesses. The Integrated Strategy on the Promotion of Entrepreneurship and Small Enterprises, the National Small Business Act No 102 of 1996, and other programmes were put into place. This integrated strategy meant to increase financial and non-financial support to small businesses, establish the increased need for products and services rendered by SMMEs and ease small business regulatory constraints. The strategy focuses on promotion of small enterprises in specified targeted groups, including youth, and certain geographical areas. As a result more and more youth in the country have begun to enter the business arena. However, how these youth-owned businesses are performing, what their challenges are, still needs to be assessed for them to be seen to be making a significant difference.

\section{Literature Review}

"Countries at all stages of development have recognised that small and medium enterprises (SMEs) are a dynamic engine for economic growth, and SME competitiveness programs are the centrepieces of many economic development initiatives" (Brodman \& Berazneva, 2007: 3). Small, Medium and Micro Enterprises (SMMEs) produce a substantial amount of international trade and contribute considerably towards the economic growth and stability of many countries. Small business enterprises tend to be innovative, creative and contribute towards the competitiveness of countries. Accordingly, there is consensus that developing countries, South Africa included, need to develop and support more small business owners to grow the economy and create more jobs (Lituchy \& Reavley, 2004; Pretorius \& van Vuuren, 2003).

It is reported that South Africa ranked $23^{\text {rd }}$ out of 43 countries in terms of entrepreneurial activity (Herrington, Kew and Kew; 2008). In addition, South Africa's early-stage entrepreneurial activity, known as the Total Entrepreneurship Activity (TEA) rate went down from 9.1\% in 2011 to $7.3 \%$ in 2012. TEA gives the rate of people aged between 18 and 64 years who are actively involved in starting businesses or in businesses that are less than 40 months old (Fatoki \& Chidonga, 2011). The TEA rate is considerably lower than the average of $14.3 \%$ in efficiency-driven countries. It also implies that there are less people starting businesses in SA as compared to other sub-Saharan countries. This underscores the country's constantly below-average trend in early-stage entrepreneurial activity as compared to other countries with a comparable level of economic development. Limpopo Province has an even lower number of early-stage entrepreneurs, - only $4 \%$ of people starting businesses are based in the province (Turton \& Herrington, 2012).

A Global Economic Monitor (GEM, 2012) survey that was comparing youth and how much they perceive/observe business opportunities in their country was conducted in South Africa and nine other sub-Saharan African countries. The results of the survey indicated that the rate of perceived opportunities by youth in SA is 39\%, which was the lowest of the sub-Saharan African countries that participated in GEM (at an average of 70\%). Young women in SA were found to have lower perceptions of opportunity and capabilities than their male counterparts. The rate of entrepreneurial intentions (i.e. those planning to start entrepreneurial ventures) among youth was found to be $15 \%$ in SA, which was the lowest of the 10 sub-Saharan African countries at an average of $56 \%$. South Africa (together with Namibia) also had the lowest established business rate in its youth (1\%), below the average for the 10 surveyed countries at $8 \%$ (Turnton \& Herrington, 2012).

Unluckily, youth-owned SMMEs in this and most other developing countries are still faced with challenges that larger businesses do not have to deal with (Lituchy \& Reavley, 2004). Research has shown that youth face a range of challenges that include lack of access to technology, no market research and/or marketing services. Youth also tend to have low educational level that is compounded by the lack of education and training in management/business skill like drawing up business plans, bookkeeping, people management and marketing skills. Furthermore, often youth, especially from rural and previously disadvantaged areas, often do not have enough savings or assets of their own to present as collateral when seeking financial assistance. Other difficulties are that youth often do not have transport of their own to collect or deliver goods or render services. As a final point, businesses in rural areas often operate under poorly developed or fragmented infrastructure that makes it difficult for them to access markets and/or customers (Basargekar, 
2007; Palaniappan, Ramanigopal, \& Mani, 2012).

Unfortunately the above challenges are prominent among SMME owners who live in the underdeveloped rural areas. According to Rogerson (2001) rural small business enterprises in South Africa have to contend with more hardships as compared to their urban counterparts. These disadvantages include the fact that rural small business enterprises often operate in impoverished areas that have corresponding high levels of unemployment. They are also faced with lower growth opportunities and are mostly involved in survivalist enterprises with very little potential to create employment or wealth. These rural small business enterprises also function with inadequate access to such basic services as water, electricity and street lighting. They frequently function in environments wherein wealth flows out to urban areas meaning that money is neither retained nor circulated locally.

Turnton \& Herrington (2012) identified further shortcomings for small business enterprises that include: restrictive labour legislation, not enough tax incentives; established businesses making it hard for emerging businesses to enter the business area due to their anti-competitive behaviour; as well as the domination by monopolies and alliances that also make it difficult for emerging businesses to penetrate the market.

To sum-up, small businesses have been seen to make a great impact on the economies of several countries. As a result, countries, South Africa included, have put measures and initiatives into place to support the development of entrepreneurship and small business enterprises. South Africa has additional policies that are specific for youth. As a result, more and more youth-owned businesses are making inroads into the business area. Thus, these youth-owned businesses need to be assessed in order to see how they are performing.

\section{Research Methodology}

This is a cross-sectional exploratory survey, using both mixed methods of data collection. The data was collected by means of designed questionnaires. The main target population was all youth-owned businesses (registered and unregistered) in the province. All identified youth-owned small enterprises were included for participation in the study. A total of 700 questionnaires were distributed to all identified youth-owned small businesses within the province. Eventually, there 435 completed questionnaires were returned for analysis.

\section{Results}

\subsection{Business Growth}

Growth of businesses was measured in terms of the increase in the number of employees in each business as well as in terms of increase in sales, profit and/or assets in the two years preceding the research. Table 2 underneath presents the findings. The majority of the participants (78\%) had neither grown bigger nor gotten smaller.

A relatively small percentage (14.3\%) reported a decrease in sales, $27 \%$ were not noticing any change, while $58 \%$ recorded an increase in sales. The increase in sales was also reported to be corresponding with the increase in profits. However, the increase in sales or profits could not be quantified exactly.

\subsection{Awareness of Training Programmes and Government Support Policies and/or Initiatives}

When the participants were asked about their knowledge and/or awareness of any initiatives by government to support youth-owned businesses the following were the results: $22 \%$ were aware of the Broad Based Black Economic Empowerment Act (BBEEE); 12\% of the Preferential Procurement Policy; 18\% were aware of Limpopo Business Support Agency (LIBSA) Programmes; 14\% of the Expanded Public Works Programme (EPWP); and a further 19\% were aware of other government offered training programmes. Over $81 \%$ of the participants indicated that they were not aware that government was offering training programmes to youth business owners, i.e. they were aware of other support measures, especially financial support.

\subsection{Business Support Received from Government}

After several government organisations and policies that offer support (financial and non-financial) to small business enterprises in the country and in the province were identified above, the participants were then asked whether they had ever used those initiatives for help with: start-up capital, money for stock, documents such as tax registration forms, training, and/or cash-flow problems. The results indicated that although in some instances they were aware of some of 
the institutions, usage of such institutions was very limited. Only 3.3\% had used a government support organisation for start-up capital; 3.3\% sought help when their businesses had cash-flow problems; $2.5 \%$ asked for help when they ran out of stock and had not enough money to replenish; $6.8 \%$ were assisted with filling documents for e.g. registering their businesses and/or for tax purposes; and $7.7 \%$ had undergone some training with the government support organisations.

When asked about why they did not utilise the support services some of them indicated that they were not aware of some of the organisations. For those organisations that they (the participants) were aware of: they did not know where the nearest offices are based; and did not know how to go about approaching them (small business support services) and/or they lacked the confidence to contact them.

\subsection{Skills Required to Start and Maintain a Business}

The participants were asked what skills they think are essential to start a business and to maintain it. The following were rated as crucial: enough start-up (own) capital; training in business skills; numeric, financial skills and knowledge of how to keep financial records and how to read financial statements; business experience and management skills, including managing people; research skills, - especially market research; negotiation skills; and drawing up business plans. Education was also rated as important. However, the participants did not rate post-matric qualifications as highly as they rated the other skills mentioned above.

\subsection{Record Keeping}

Another question that was asked was aimed at finding out whether the participants keep records of their transactions/sales and supplies. Thirty two per cent (32\%) of the participants indicated that they do not keep any records in their businesses. Thirty three per cent (33\%) of those who keep records utilise the services of either a bookkeeper or auditor while the rest of them compile their own records.

\subsection{Reasons for Initiating Businesses}

The participants were also asked why they chose to enter into business ventures. The following are some of the reasons that were given: $80 \%$ of them were not employed; of those that were unemployed $20 \%$ of them were retrenched; the need to be independent of government, family, friends and others was also stated by many of the participants; the need for achievement; as well as joining family businesses.

The above reasons for starting businesses are also considered to be the push and pull factors or motivational factors for people to choose businesses (Dawson, Henley \& Latreille: 2009). The results thus indicate that the participants are mostly driven by necessity and/or the need to go into business rather than entrepreneurial intention or seizing opportunity(ies) (Caliendo \& Kritikos: 2009).

\subsection{Challenges Experienced by Youth-Owned Businesses}

Amongst some of the challenges identified by the research participants: lack of confidence to approach potential clients, potential creditors as well as people that can potentially mentor them; not enough finance to run their businesses in terms of marketing themselves and growing their businesses (buying new products that can help in diversifying or growing).

Lack of the following skills was also identified amongst the challenges experienced: marketing skills including how to conduct a marketing research; managing people: some of them reported that some of their employees are not controllable while it is not easy to get rid of those employees; financial record-keeping skills: as a result some of the participants either do not keep proper books or they have to do that at a cost, which they can barely afford; technological skills that could be helpful in terms of accessing new markets and/or marketing their businesses; writing of business plans, which would aid in them having confidence to present themselves to potential creditors. In addition, writing a business plan gives one an opportunity to look at the feasibility of the business as well as forecasting the future prospects of an enterprise.

Another challenge identified in the research was lack of access to appropriate technology: (i.e. computers and the internet, telephones, fax machines). Again this has the potential to help youth business owners access bigger markets and grow.

Research participants further mentioned challenges of underdeveloped or not well-maintained infrastructure in terms of: roads not in good condition in such a way that sometimes suppliers do not reach them (e.g. in very wet weather) 
or they, the small business owners, are unable to reach their suppliers or customers; or street lights not being there, or when they are there they are not always working well, implying that small businesses have to have shorter operational hours

\section{Conclusion and Recommendations}

The paper concludes and makes recommendations as follows:

Lack of confidence: research participants showed that they do not have confidence in themselves implying that they may not be able to seek help even when they need it or market themselves even in areas where they can make a contribution. Lack of confidence can also be due to being unsure of what needs to be done or reasons why something needs to be done. Therefore, it is recommended that participants should receive education and training in overall business management and in the industries or areas of their specific businesses to gain confidence in what they are doing. Furthermore, learning, education and training can also be from mentors who have been in business longer than youth who are just entering the business arena. Peer education, learning from one another can also be helpful. In the same vein, partnerships and joint ventures can help in developing small youth-owned businesses.

Lack of awareness of available resources: participants were still not fully aware of government resources (financial and non-financial) that are available to them. As a result they still have problems accessing these services. This is one of the reasons they still have financial challenges in terms of accessing finance to grow their businesses. This is further complicated by the fact that they do not have confidence in themselves and they cannot write business plans which would be required when approaching potential creditors. This paper thus recommends that these government small business support agencies should advertise themselves more, especially in rural areas. There should also be specialised workshops focusing on educating youth about services and/or agencies that are available for their support and development, what kind of services these organisations render, how youth can access these services and what they stand to gain by approaching them. Furthermore, these support organisations can promote and market themselves in local indigenous languages that youth business owners (and other interested people) can understand. The advertising can also be in areas that have high traffic for the support organisations to be more visible. Those organisations should also consider having smaller/satellite branches in rural communities.

Access to finance: The research results further indicated that although some of the government funding and support agencies have been in existence for several years, they are still not known by youth who are in business, and, most importantly, even those that are known are still not utilised. This links to the need for these support institutions to be more visible by promoting and advertising themselves more through means like workshops.

Youth business owners still do not access commercial banks, in part because the banks still need collateral to give out a loan, but also because rural people, especially youth, dread contacting them. Fearing to approach banks links yet again with the lack of confidence, poor communication and negotiation skills of the participants. This fear of approaching potential funders, highlights, yet again, the importance of training in this area.

Lack of skills: The results suggested that the youth did not have skills in different areas of business management, i.e. in marketing management, managing people, financial and bookkeeping skills, communication and negotiation skills and writing of business plans that include forecasting. This lack of skills highlights the importance of education and training. Additionally, the focus on 'entrepreneurship' as one of the school subjects should commence early, in primary school, as there are some of the participants' education level at or below matric. The education is expected to make individuals aware of prospects of entrepreneurship and self-employment at an early age.

Business mentoring and coaching: Youth business owners should be helped in identifying more established business owners who would be willing to coach and mentor them. The mentors/coaches can then hopefully guide youth through the process of starting, growing and maintaining their businesses. Coaching and mentoring can also be a way of grooming young business owners and helping them to develop confidence in running their own businesses.

Encourage partnerships and joint ventures: These partnerships and ventures can afford youth a chance to learn from one another and gain from skills they do not have that their partners would perhaps have. Besides, merging their finances, skills and other resources could possibly help youth in developing a bigger pool of resources and then be able to access wider markets. Partnerships and joint ventures are envisaged to help to grow youth-owned businesses, create more employment opportunities and aid in alleviating poverty in their area of operation.

Infrastructural challenges: provision as well as maintenance of amenities such as roads, street lighting, water and sanitation are some of the matters that will need to be addressed by the government and business structures that are responsible for them. Making sure that there is adequate lighting in all areas. 
Most of the youth in this research did not start their businesses because of seeing opportunities, they mostly started because they were not employed and needed to survive (except for the few who were joining family businesses). This links with the recommendation that there is need to educate and start inculcating a culture of entrepreneurship early. The culture of entrepreneurship will hopefully encourage people, especially youth, to start looking for business opportunities and seeing operating businesses as a way of life rather than it being the last resort or the need to survive.

Overall, the youth-owned businesses surveyed in this research were still small, with an average of five employees, thus making very little impact on the alleviation of poverty in their areas of operation.

The significance of the paper is its emphasis on a subject that is contemporary and significant to the development and empowerment of youth in especially rural areas of the Limpopo Province of South Africa. Thus, it is applicable to economic development concerns that include generation of income, poverty alleviation and increase in entrepreneurial activity, mainly in rural areas. The results further relate to how youth can be helped to be better, more sustainable business owners who contribute significantly to the local economy. The significance of the paper is to further draw attention to what government and other stakeholders may do to have a greater impact for these youth-owned businesses. The worth of small businesses to the economic growth of any country is another reason why the success of youth-owned small business is so important.

Further research needs to be conducted on how youth-owned small businesses can be assisted to grow and contribute to the reduction of unemployment as well as evaluating successful small enterprise to see what makes them succeed where others are not flourishing.

\section{References}

Basargekar, P (2007). Women entrepreneurs: Challenges faced. ICFAI Journal of Entrepreneurship Development, 4 (4), 6 - 25.

Brodman, J \& Berazneva J. (2007). Transforming opportunities for women entrepreneurs. Information Technology and International Development, 4, (2), 3 - 10.

Caliendo, M., \& Kritikos, A. S. (2009). "I Want to, But I Also Need to": Start-Ups Resulting from Opportunity and Necessity. Discussion Paper Series, Swansea University, Bonn, Germany.

Dawson, C., Henley, A, \& Latreille, P. (2009). Why Do Individuals Choose Self-Employment? Discussion Paper Series, Swansea University, Bonn, Germany.

Fatoki, O. \& Chidonga, L. (2011). An investigation into the obstacles to youth entrepreneurship in South Africa. International Business Research, 4 (2), $161-169$.

Herrington, M, Kew J. \& Kew P. (2008). Global Entrepreneurship Monitor. UCT Graduate School of Business: Cape Town

Lituchy, T.R. \& Reavley, M.A. (2004). Women entrepreneurs: A comparison of international small business owners in Poland and Czech Republic. Journal of International Entrepreneurship, 2, $61-87$.

Palaniappan, G., Ramanigopal, C. S. \& Mani, A. (2012). A paper on problem and prospects of women entrepreneurs with special reference to Erode District. International Journal of Physical and Social Science, 2 (3), 219 - 230.

Pretorius, M. and van Vuuren, J. (2003). Contribution of support and incentive programs to 1entrepreneurial orientation and start-up culture in South Africa. SAJEMS NS 6 (3), $514-528$.

Rogerson, C. M. (2001). Towards a framework for rural SMME development in South Africa. In, Khosa, M. M., Empowerment through economic transformation. Pretoria: HSRC Press.

South Africa. (2008). Department of Trade and Industry. Annual review of Small business in South Africa 2005-2007.

South Africa. Department of Trade and Industry. Integrated Strategy on the Promotion of Entrepreneurship and Small Enterprises: unlocking the potential of South African entrepreneurs. Pretoria.

South Africa. The Department of Trade and Industry. The National Youth Economic Empowerment Strategy: Mainstreaming youth in the South African Economy, 2009 - 2019. Pretoria.

South Africa. (2008). National Youth Policy, 2009 - 2014. Pretoria: Government Printers.

South Africa. The Department of Trade and Industry. Youth Enterprise Development Strategy [YEDS], (2013 - 2030). Creating New Business Opportunities for Young Women and Men in South Africa. Pretoria.

Statistics South Africa. (2014). Quarterly Labour Force Survey, Quarter 4, 2013. Statistical release P01211. Pretoria: StatsSA.

Statistics South Africa. (2013). Mid-year population estimates 2013. Statistical release P0302. Pretoria: StatsSA.

Turton, N. \& Herrington, M. (2012). Global Entrepreneurship Monitor South Africa. UCT Graduate School of Business: Cape Town, SA. 